\title{
Quarterly Report on the
} Strontium Heat Source

Development Program, Advanced Nuclear Systems and Projects Division for July-September 1979

H.T. Fullam

October 1979

Prepared for the U.S. Department of Energy under Contract EY-76-C-06-1830

Pacific Northwest Laboratory Operated for the U.S. Department of Energy by Battelle Memorial Institute 
This report was prepared as an account of work sponsored by the United States Government. Neither the United States nor the Department of Energy, nor any of their employees, nor any of their contractors, subcontractors, or their employees, makes any warranty, express or implied, or assumes any legal liability or responsibility for the accuracy. completeness or usefulness of any information, apparatus, product or process disclosed, or represents that its use would not infringe privately owned rights.

The views, opinions and conclusions contained in this report are those of the contractor and do not necessarily represent those of the United States Government or the United States Department of Energy.

\author{
PACIFIC NORTHWEST LABORATORY \\ operated by \\ BATTELLE \\ for the \\ UNITED STATES DEPARTMENT OF ENERGY \\ Under Contract EY-76-C-06-1830
}

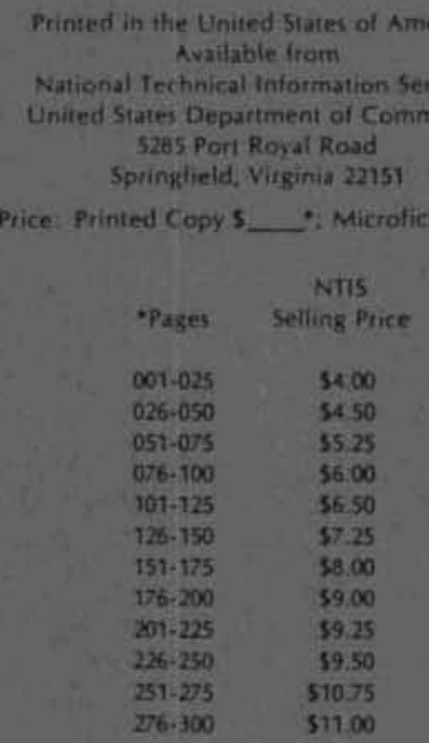


QUARTERLY REPORT ON THE STRONTIUM HEAT SOURCE DEVELOPMENT PROGRAM, ADVANCED NUCLEAR SYSTEMS AND PROJECTS DIVISION FOR JULY-SEPTEMBER 1979

H. T. Fullam

October 1979

Prepared for

the U.S. Department of Energy under Contract EY-76-C-06-1830

Pacific Northwest Laboratory

Richland, Washington 99352 


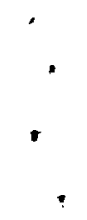




\section{SUMMARY}

Metallographic examination of the metal specimens exposed to ${ }^{90} \mathrm{SrF}_{2}$ for $20,000 \mathrm{~h}$ was completed, as was the examination of the specimens exposed to nonradioactive $\mathrm{SrF}_{2}$ for 30,000 hours.

Fabrication and welding of the prototype capsules to be used in the qualification testing program was completed. 
' 


\section{CONTENTS}

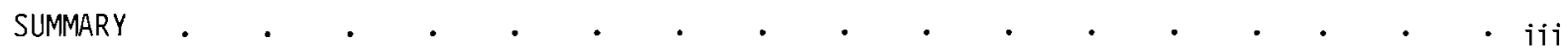

STRONTIUM HEAT SOURCE DEVELOPMENT PROGRAM

TASK 1 - CHEMICAL AND PHYSICAL PROPERTIES OF $90 \mathrm{SrF}_{2}$

TASK 2 - 90SrF 2 COMPATIBILITY STUDIES

TASK 3 - CAPSULE QUALIFICATION AND LICENSING

Capsule Design

Capsule Fabrication and Testing

Oxidation of Hastelloy $\mathrm{S}$ and Hastelloy $\mathrm{C}-4$

1
1
1
10
10
10
10




\section{FIGURES}

1 Hastelloy C-276 Specimens Exposed to ${ }^{90} \mathrm{SrF}_{2}$ for $20,000 \mathrm{~h}$ - Capsule

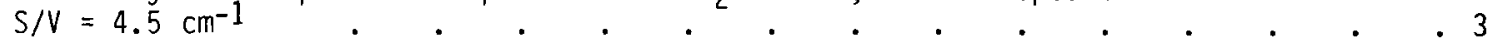

2 Haynes Alloy 25 Specimens Exposed to $90 \mathrm{SrF}_{2}$ for $20,000 \mathrm{~h}$ - Capsule $S / V=4.5 \mathrm{~cm}^{-1}$. $\quad . \quad . \quad . \quad . \quad . \quad . \quad . \quad . \quad . \quad . \quad . \quad . \quad . \quad .44$

3 TZM Specimens Exposed to ${ }^{90} \mathrm{SrF}_{2}$ for $20,000 \mathrm{~h}-$ Capsule $\mathrm{S} / \mathrm{V}=4.5 \mathrm{~cm}^{-1} \quad$. 5

4 Hastelloy C-276 Specimens Exposed to Nonradioactive SrF2 for $30,000 \mathrm{~h}$ - Capsule

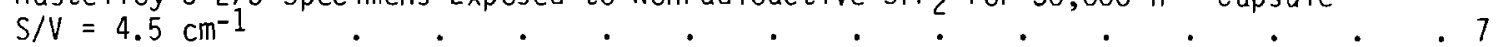

5 Haynes Alloy 25 Specimens Exposed to Nonradioactive SrF 2 for $30,000 \mathrm{~h}$ - Capsule $S / N=4.5 \mathrm{~cm}^{-1}$.

6 TZM Specimens Exposed to Nonradioactive $S_{r F}$ for 30,000 $n$ - Capsule $S / V=4.5 \mathrm{~cm}^{-1}$

\section{TABLES}

1 Estimated Attack of Metal Specimens Exposed to ${ }^{90} \mathrm{SrF}_{2}$ - Capsule $S / V=4.5 \mathrm{~cm}^{-1}$

2 Attack of Metal Samples Exposed to Nonradioactive SrF 2 - Capsule $\mathrm{S} / \mathrm{V}=4.5 \mathrm{~cm}^{-1}$ 
H. H. Van Tuyl, Program Manager

H. T. Fullam, Principal Investigator

D. G. Atteridge

F. A. Simonen

At Hanford, strontium is separated from the high-level waste, converted to the fluoride, and doubly encapsulated in sma11, high-integrity containers for subsequent long-term storage. The fluoride conversion, encapsulation, and storage take place in the Waste Encapsulation and Storage Facilities (WESF). The encapsulated strontium fluoride represents an economical source of $90 \mathrm{Sr}$ if the WESF capsule can be licensed for heat-source applications under anticipated-use conditions. The objectives of this program are to obtain the data needed to license ${ }^{90} \mathrm{SrF}_{2}$ heat sources, and specifically the WESF ${ }^{90} \mathrm{SrF}_{2}$ capsules. The information needed for licensing can be divided into three general task areas:

Task 1 - Chemical and Physical Properties of ${ }^{90} \mathrm{SrF}_{2}$

Task $2-{ }^{90} \mathrm{SrF}_{2}$ Compatibility Studies

Task 3 - Capsule Qualification and Licensing

Efforts are proceeding concurrently on all three tasks to obtain the required information.

TASK 1 - CHEMICAL AND PHYSICAL PROPERTIES OF ${ }^{90} \mathrm{SrF}_{2}$ (H. T. Fullam)

No activity this quarter.

TASK $2-{ }^{90} \mathrm{SrF}_{2}$ COMPATIBILITY STUDIES (H. T. Fu1lam)

Metallographic examination of the metal specimens from the 20,000-h tests with ${ }^{90} \mathrm{SrF}_{2}$ has been completed by Oak Ridge National Laboratory (ORNL). Estimates of metal attack based on the photomicrographs obtained are given in Table 1, together with the results of the shorter-duration tests. Micrographs of the various metal specimens are shown in Figures 1 through 3. Attack of the $20,000-h$ metal specimens was not significantly greater than that observed in the 12,000-h tests, except for the two Haste110y C-276 samples tested at $1000^{\circ} \mathrm{C}$. Attack of the two specimens was much greater than anticipated based on earlier results, since all of the other compatibility test results show a marked decrease in the rate of metal attack after 6000-to 12,000- $h$ exposure. Reasons for the increased attack of the two Hastelloy $\mathrm{C}-276$ samples have not been determined.

Metallographic examination of the metal specimens exposed to nonradioactive SrF 2 for $30,000 \mathrm{~h}$ has been completed. The results obtained are presented in Table 2, and micrographs of the various specimens are shown in Figures 4 through 6 . The extent of metal attack was very similar to that observed in the $6000-h, 12,000-h$ and $20,000-h$ tests.

Samples from the inner capsule of the WESF ${ }^{90} \mathrm{SrF}_{2}$ storage capsule, which was held at $800^{\circ} \mathrm{C}$ for $3 \mathrm{yr}$, were shipped to ORNL. Metallographic examination of the samples is now under way. 
TABLE 1. Estimated Attack of Metal Specimens Exposed to ${ }^{90} \mathrm{SrF}_{2}$, Capsule $S / \mathrm{V}^{(\mathrm{a})}=4.5 \mathrm{~cm}^{-1}$

\begin{tabular}{|c|c|c|c|c|c|c|c|c|c|}
\hline \multirow[b]{3}{*}{ Material } & \multirow{3}{*}{$\begin{array}{c}\text { Temperature, } \\
\mathrm{o}_{\mathrm{C}} \\
\end{array}$} & \\
\hline & & 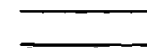 & Chemi & IAttack & 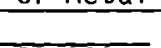 & 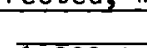 & Changes $\mathrm{i}$ & Microstrue & \\
\hline & & $1,000 \mathrm{~h}$ & $6,000 \mathrm{~h}$ & $12,000 \mathrm{~h}$ & $20,000 \mathrm{~h}$ & $1,000 \mathrm{~h}$ & $6,000 \mathrm{~h}$ & $12,000 \mathrm{~h}$ & $20,000 \mathrm{~h}$ \\
\hline$\overline{\text { Hastel loy C- } 276}$ & 600 & 3 & 3 & 5 & 8 & 4 & 4 & 7 & 10 \\
\hline Haste17oy C- 276 & 600 & 3 & 3 & 7 & 4 & 5 & 5 & 10 & 6 \\
\hline Hastelloy C-276 & 800 & 7 & 8 & 12 & 7 & 12 & 20 & 25 & 10 \\
\hline Haste1 loy C-276 & 800 & 6 & (b) & 11 & 10 & 11 & (b) & 18 & 12 \\
\hline Hastelloy C-276 & 1,000 & 7 & 8 & 20 & 35 & 15 & 24 & $>60$ & $>40$ \\
\hline Haste11 oy C-276 & 1,000 & 10 & 12 & & 30 & 15 & $>30$ & & $>40$ \\
\hline Haynes 25 & 600 & 1 & 3 & 4 & 3 & 0 & 0 & 4 & 5 \\
\hline Haynes 25 & 600 & 2 & 5 & 3 & 7 & 0 & 0 & 4 & 8 \\
\hline Haynes 25 & 800 & 5 & 10 & 6 & 5 & 10 & 16 & 8 & 8 \\
\hline Haynes 25 & 800 & 4 & 11 & 7 & 7 & 6 & 18 & 10 & 12 \\
\hline Haynes 25 & 1,000 & 6 & 12 & 10 & 10 & 8 & 18 & 25 & $>30$ \\
\hline Haynes 25 & 1,000 & 7 & 10 & & 13 & 9 & 10 & & 25 \\
\hline TZM & 600 & 1 & 4 & 1 & 2 & 0 & 0 & 0 & 3 \\
\hline TZM & 600 & 2 & 1 & 2 & 3 & 0 & 0 & 0 & 3 \\
\hline TZM & 800 & 2 & 2 & 2 & 2 & 0 & 0 & 2 & 3 \\
\hline TZM & 800 & 2 & 2 & 2 & 2 & 0 & 0 & 0 & 3 \\
\hline TZM & 1,000 & 2 & 2 & 3 & 2 & 0 & 35 & 0 & $>30$ \\
\hline TZM & 1,000 & 1 & 2 & & 3 & 0 & 35 & & 4 \\
\hline
\end{tabular}

(a) $S / V=$ metal surface-to- ${ }^{90} \mathrm{SrF}_{2}$ volume ratio of the test couple.

(b) Specimen lost due to furnace malfunction. 
$600^{\circ} \mathrm{C}$

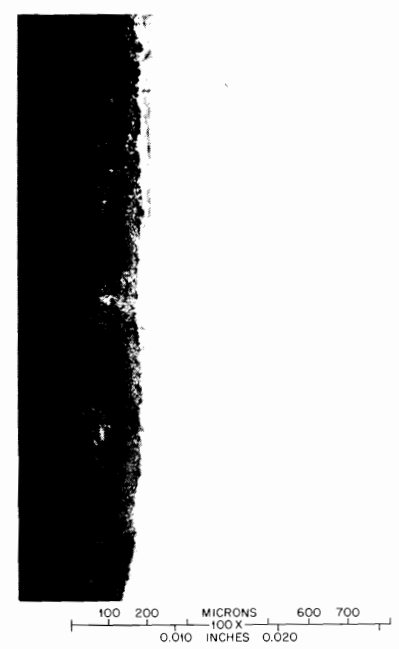

$\omega$ $800^{\circ} \mathrm{C}$
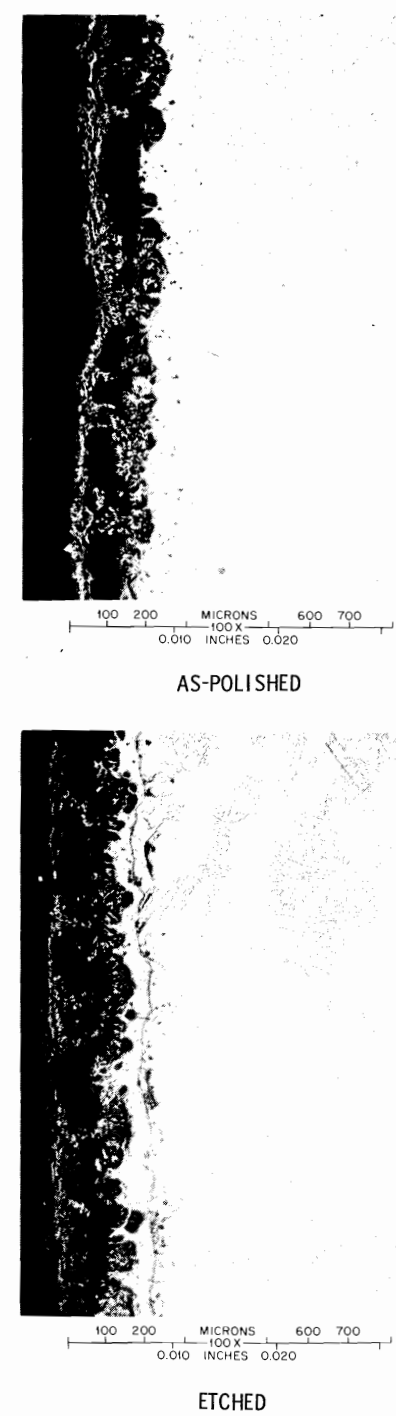

$1000^{\circ} \mathrm{C}$

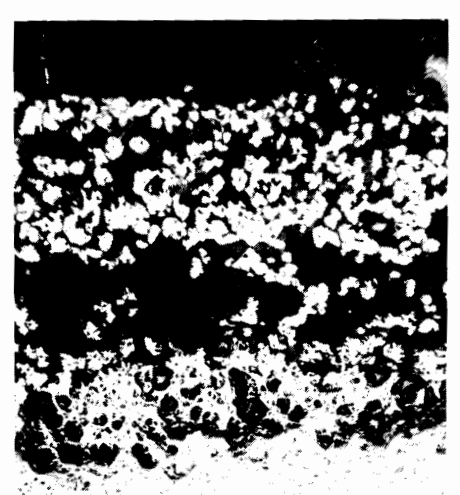

$x$
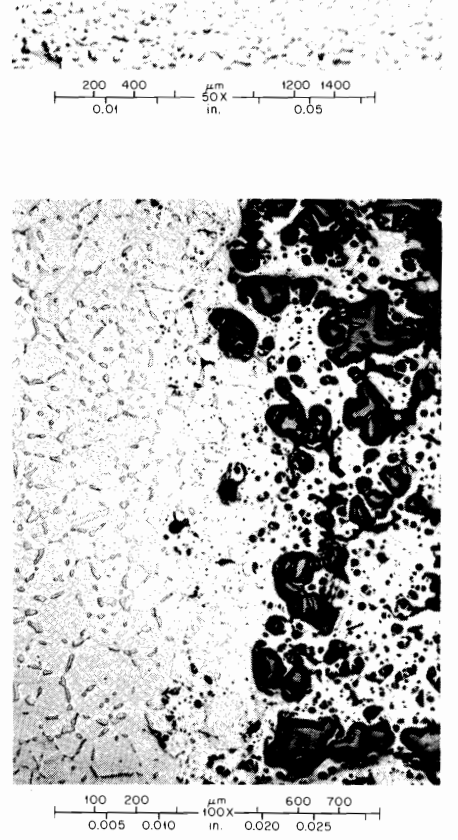

FIGURE 1. Hastelloy C-276 Specimens Exposed to ${ }^{90} \mathrm{SrF}_{2}$ for $20,000 \mathrm{~h}$ - Capsule $\mathrm{S} / \mathrm{V}=4.5 \mathrm{~cm}^{-1}$ 

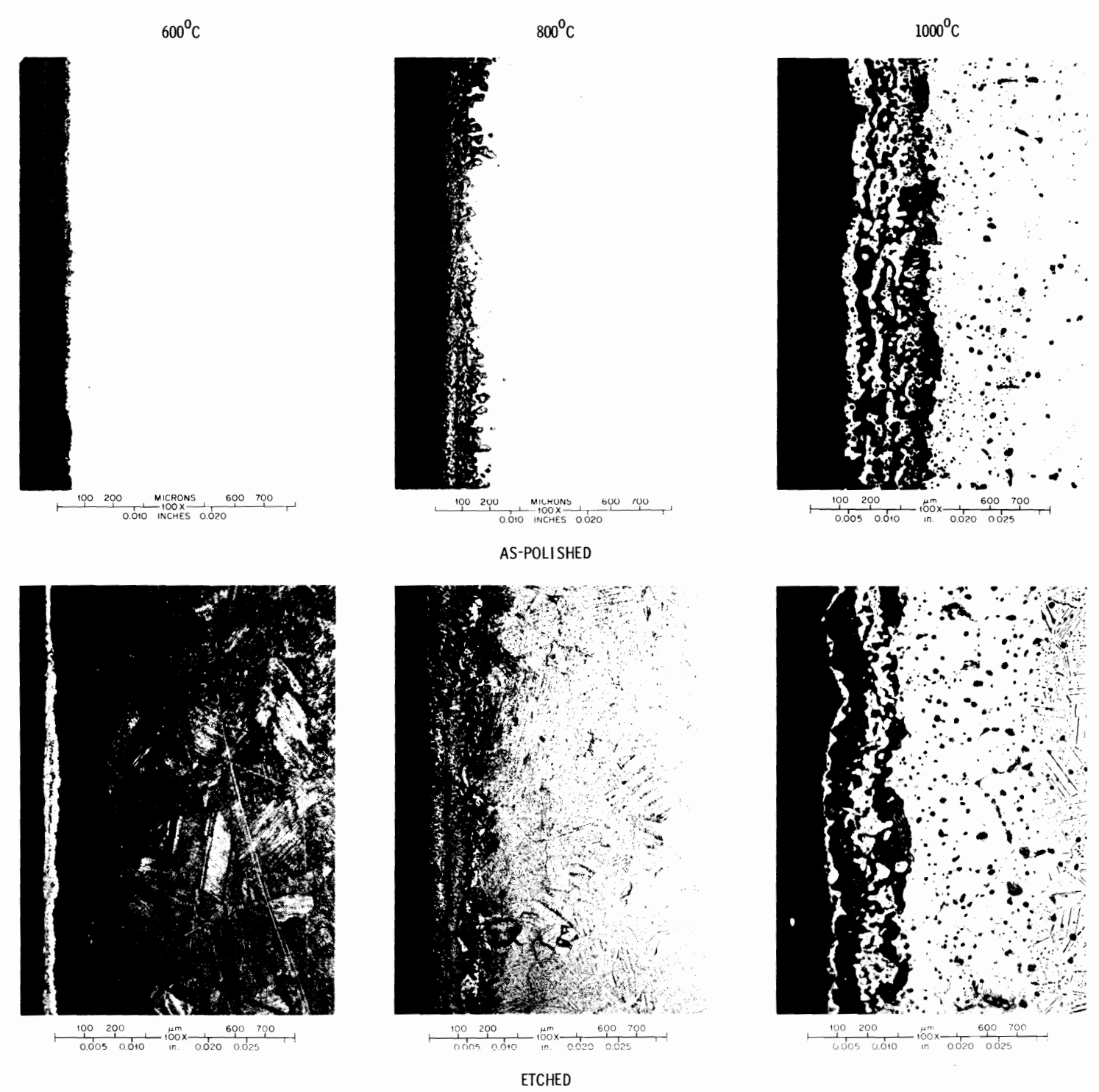

FIGURE 2. Haynes Alloy 25 Specimens Exposed to ${ }^{90} \mathrm{SrF}_{2}$ for $20,000 \mathrm{~h}$ - Capsule $S / \mathrm{V}=4.5 \mathrm{~cm}^{-1}$ 


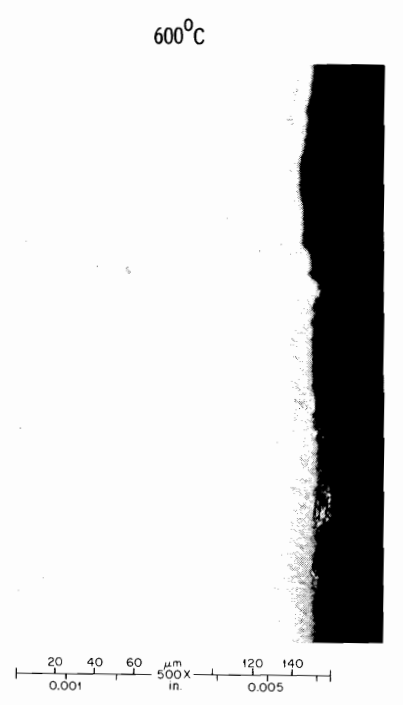

$800^{\circ} \mathrm{C}$
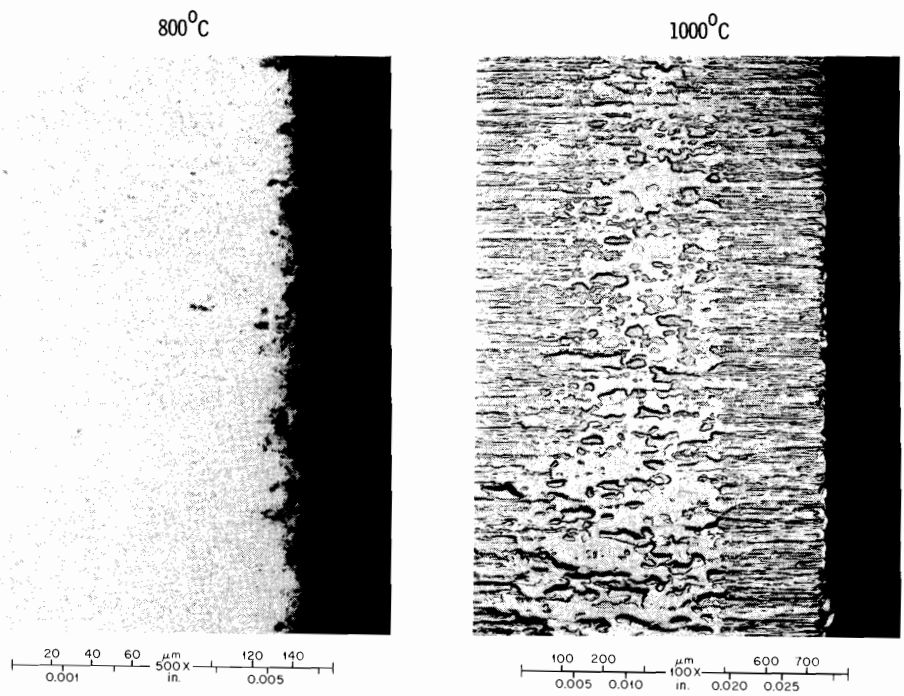

AS-POLI SHED

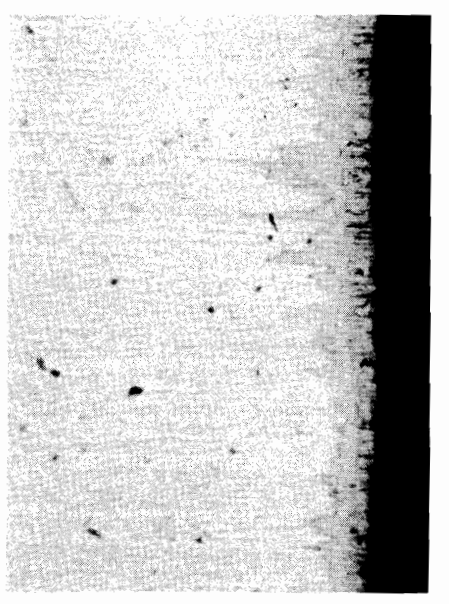

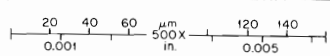
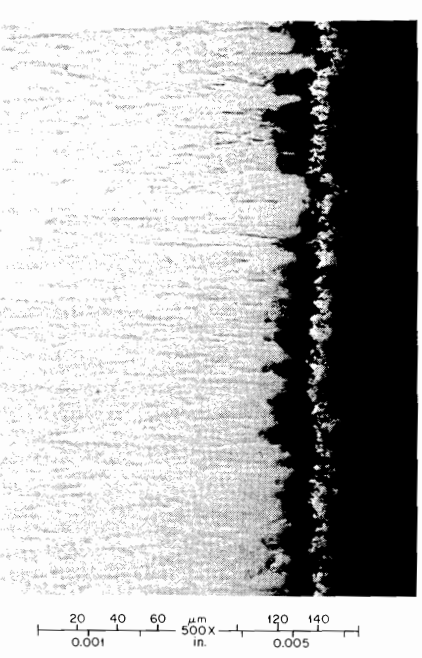

ETCHED

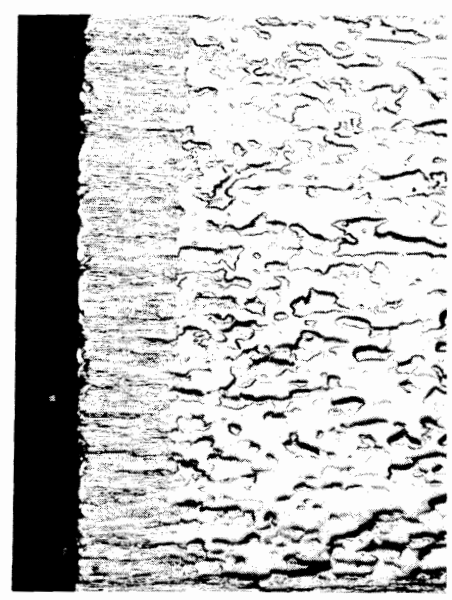

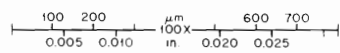

FIGURE 3. TZM Specimens Exposed to ${ }^{90} \mathrm{SrF}_{2}$ for $20,000 \mathrm{~h}-$ Capsule $S / V=4.5 \mathrm{~cm}^{-1}$ 
TABLE 2. Attack of Metal Samples Exposed to Nonradioactive $\mathrm{SrF}_{2}$, (a) Capsule $S / \mathrm{V}=4.5 \mathrm{~cm}^{-1}$ (b)

\begin{tabular}{|c|c|c|c|c|c|c|c|c|c|c|c|}
\hline \multirow[b]{2}{*}{$\begin{array}{c}\text { Material } \\
\text { Tested }\end{array}$} & \multirow[b]{2}{*}{$\begin{array}{l}\text { Temp. } \\
\text { OC }\end{array}$} & \multicolumn{10}{|c|}{ Depth of Metal Affected, mils $(\mathrm{c})$} \\
\hline & & $1000 \mathrm{~h}$ & $\frac{\text { Chemic }}{6.000 \mathrm{~h}}$ & Attack & $20000 h$ & $30000 h$ & 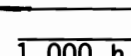 & lange in $\mathrm{N}$ & rostructur & 30000 & $30.000 \mathrm{~h}$ \\
\hline Hast C-276 & 600 & $\frac{1,000}{<1}$ & $\frac{0,000111}{3}$ & $\frac{1<, 00011}{2}$ & $\frac{0,000 n}{1}$ & $\frac{30,000}{1}$ & $\frac{1,000}{0}$ & $\frac{0,000 ~}{4}$ & $\frac{12,000 \mathrm{~h}}{8}$ & $\frac{20,000 \mathrm{n}}{6}$ & $\frac{30,000 n}{5}$ \\
\hline Hast C-276 & 600 & 1 & 4 & 2 & 1 & 1 & 5 & 5 & 7 & 4 & 3 \\
\hline Hast C-276 & 800 & $<1$ & 2 & 2 & 3 & 1 & $<1$ & 3 & 3 & 4 & 2 \\
\hline Hast C-276 & 800 & 1 & 2 & 2 & 2 & 2 & 3 & 3 & 2 & 2 & 2 \\
\hline Hast C-276 & 1,000 & 2 & 2 & 4 & 3 & 3 & 4 & 6 & 7 & 6 & 4 \\
\hline Hast C-276 & 1,000 & 3 & 3 & 2 & 3 & 3 & 4 & 7 & 8 & 5 & 6 \\
\hline Haynes 25 & 600 & $<1$ & 2 & 2 & 2 & 1 & 5 & 3 & 2 & 0 & 0 \\
\hline Haynes 25 & 600 & $<1$ & 1 & 2 & 2 & 2 & 3 & 2 & $<1$ & 0 & 0 \\
\hline Haynes 25 & 800 & $<1$ & 3 & 3 & 2 & 2 & 3 & 6 & 4 & 2 & 3 \\
\hline Haynes 25 & 800 & $<1$ & 3 & 3 & 3 & 3 & 1 & 4 & 5 & 2 & 4 \\
\hline Haynes 25 & 1,000 & 2 & 3 & 4 & ${ }_{25}(\mathrm{~d})$ & $22^{(d)}$ & 1 & 7 & 4 & 4 & 4 \\
\hline Haynes 25 & 1,000 & 2 & 3 & 3 & $18^{(d)}$ & $20^{(d)}$ & 1 & 4 & 12 & 5 & 5 \\
\hline TZM & 600 & 0 & $<1$ & 0 & $<1$ & $<1$ & 0 & 0 & 0 & 0 & 0 \\
\hline TZM & 600 & $<1$ & $<1$ & - & $<1$ & $<1$ & 0 & 0 & - & 0 & 0 \\
\hline TZM & 800 & $<1$ & $<1$ & $<1$ & $<1$ & $<1$ & 0 & 0 & 0 & 0 & 0 \\
\hline TZM & 800 & $<1$ & $<1$ & $<1$ & $<1$ & $<1$ & 0 & 0 & 0 & 0 & 0 \\
\hline TZM & 1,000 & $<1$ & $<1$ & $<1$ & $<1$ & $<1$ & 0 & 0 & 0 & 0 & $<1$ \\
\hline TZM & 1,000 & 1 & $<1$ & $<1$ & $=1$ & $<1$ & 0 & 0 & 0 & 0 & $<1$ \\
\hline
\end{tabular}

(a) The $\mathrm{SrF}_{2}$ contained impurities similar to those found in WESF ${ }^{90} \mathrm{SrF}_{2}$.

(b) Each test fouple had an exposed metal surface-to- $\mathrm{SrF}_{2}$ volume ratio (S/V)

(c) Estimated from specimen photomicrographs.

(d) Specimen exhibited a few isolated voids to a considerable depth. 
$600^{\circ} \mathrm{C}$
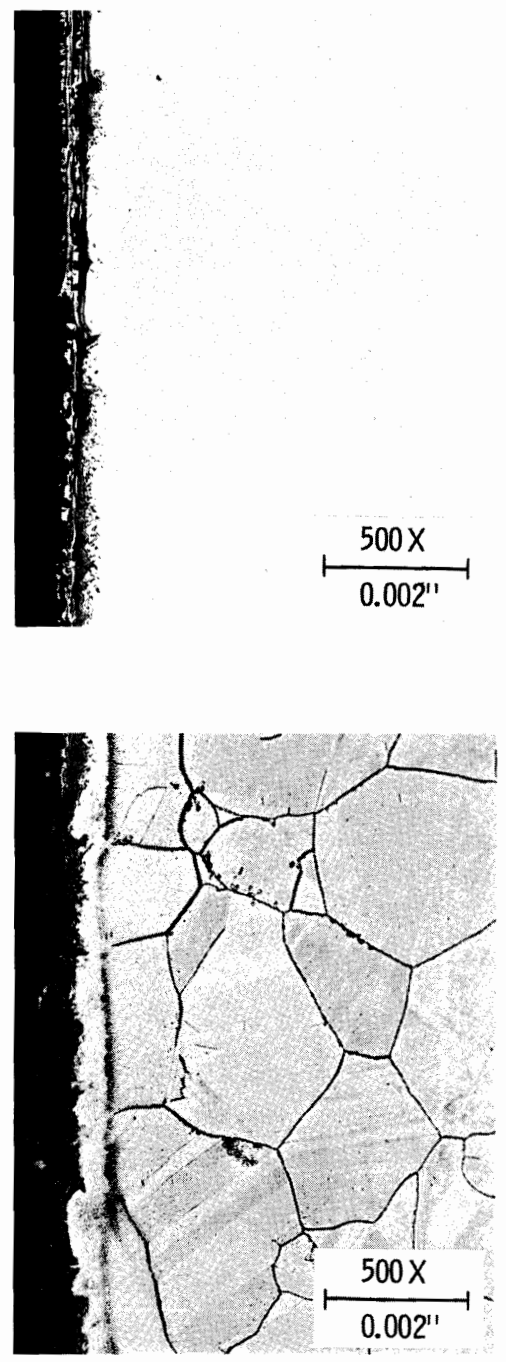

$800^{\circ} \mathrm{C}$

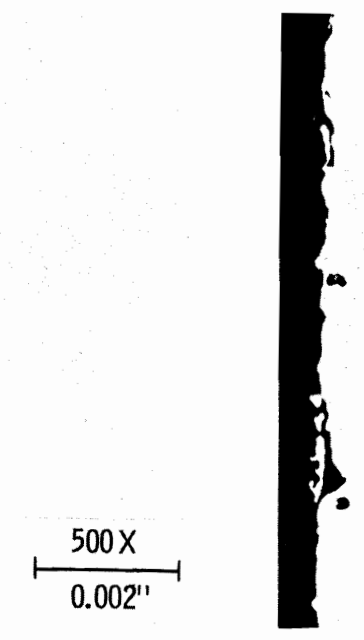

$1000^{\circ} \mathrm{C}$
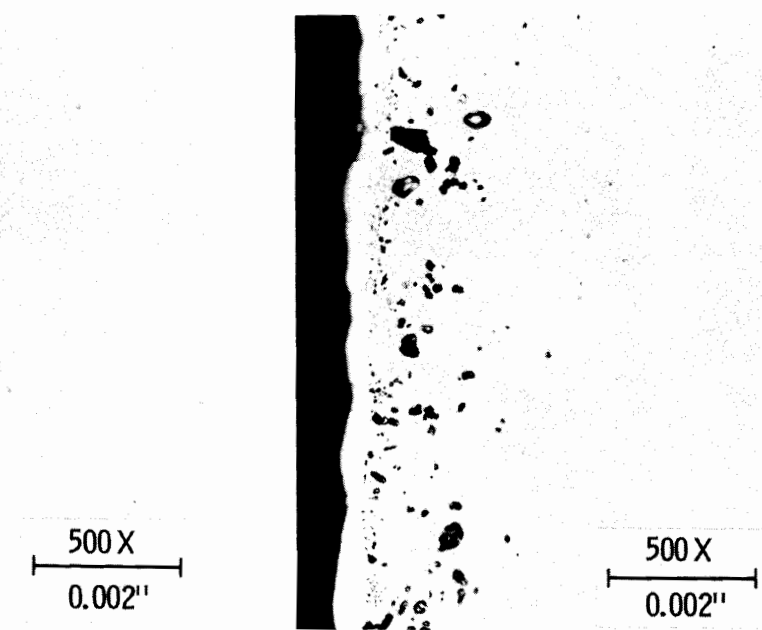

AS-POLISHED
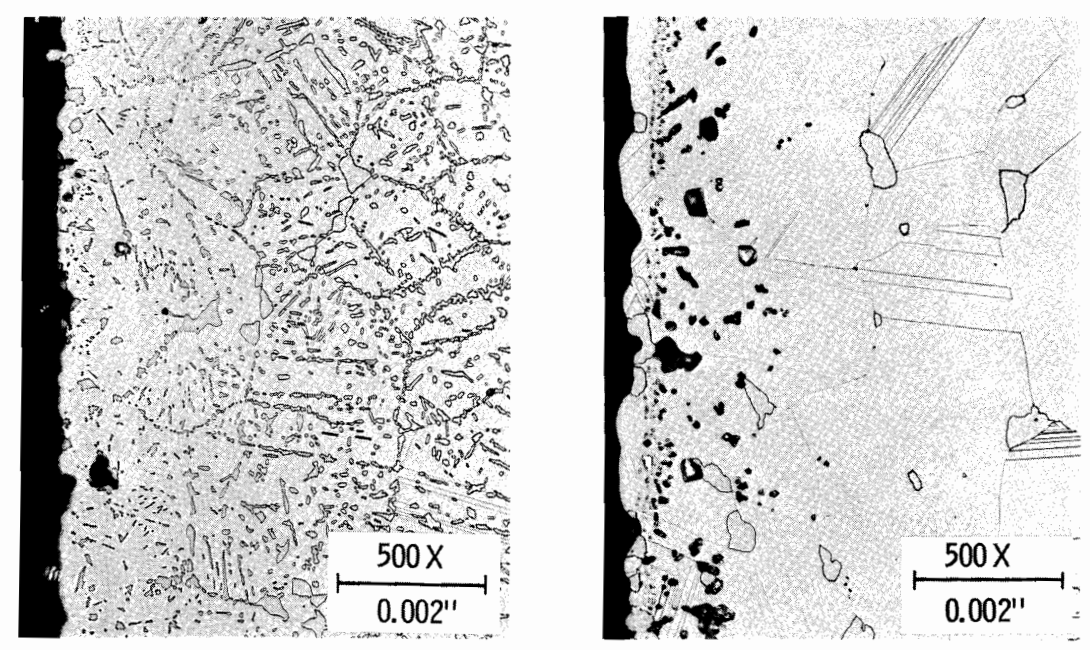

\section{ETCHED}

FIGURE 4. Hastelloy C-276 Specimens Exposed to Nonradioactive $\mathrm{SrF}_{2}$ for $30,000 \mathrm{~h}-$ Capsule $\mathrm{S} / \mathrm{V}=4.5 \mathrm{~cm}^{-1}$ 


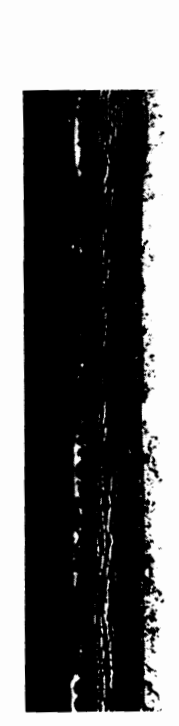

$600^{\circ} \mathrm{C}$

$800^{\circ} \mathrm{C}$

$1000^{\circ} \mathrm{C}$
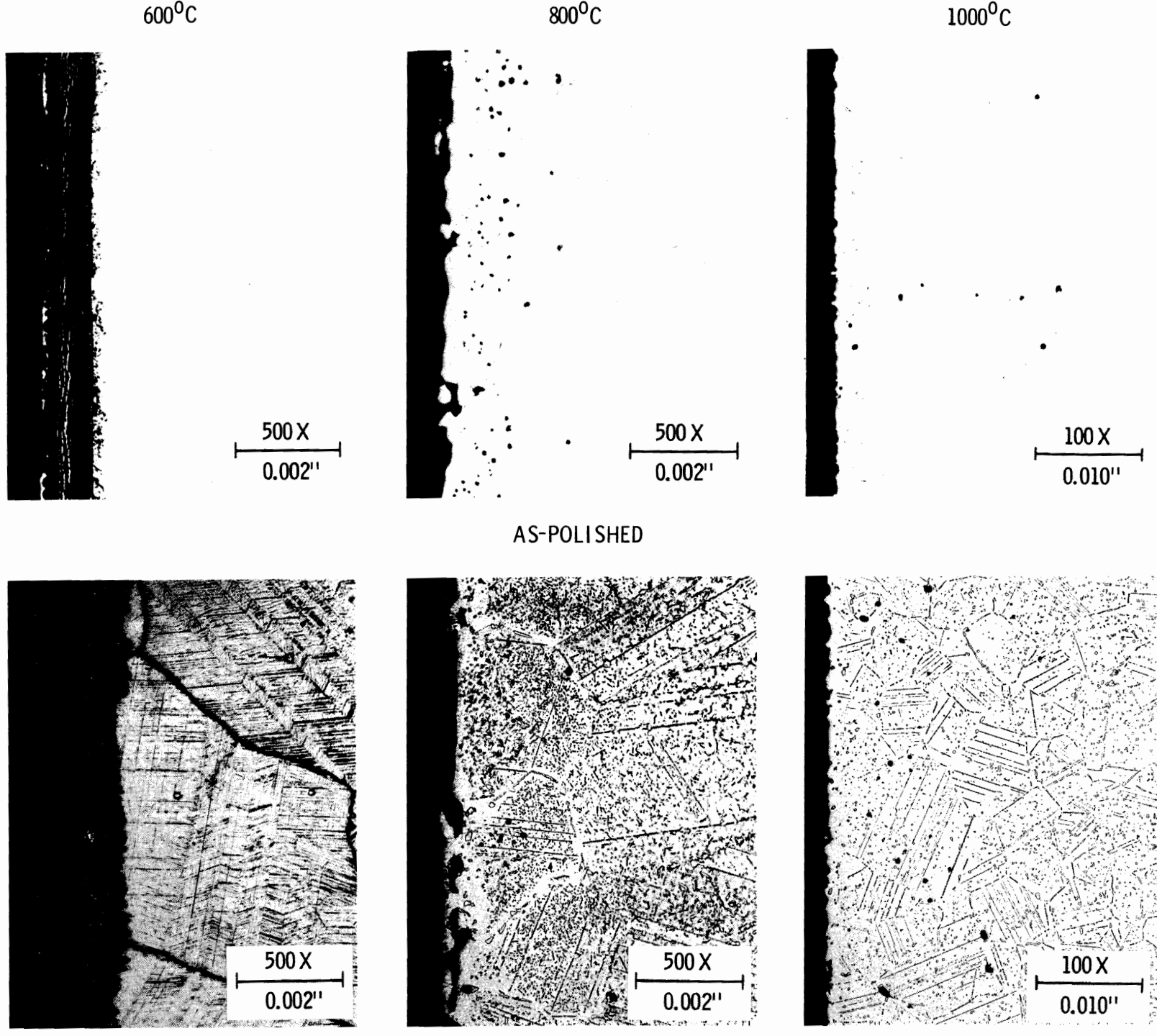

AS-POLISHED
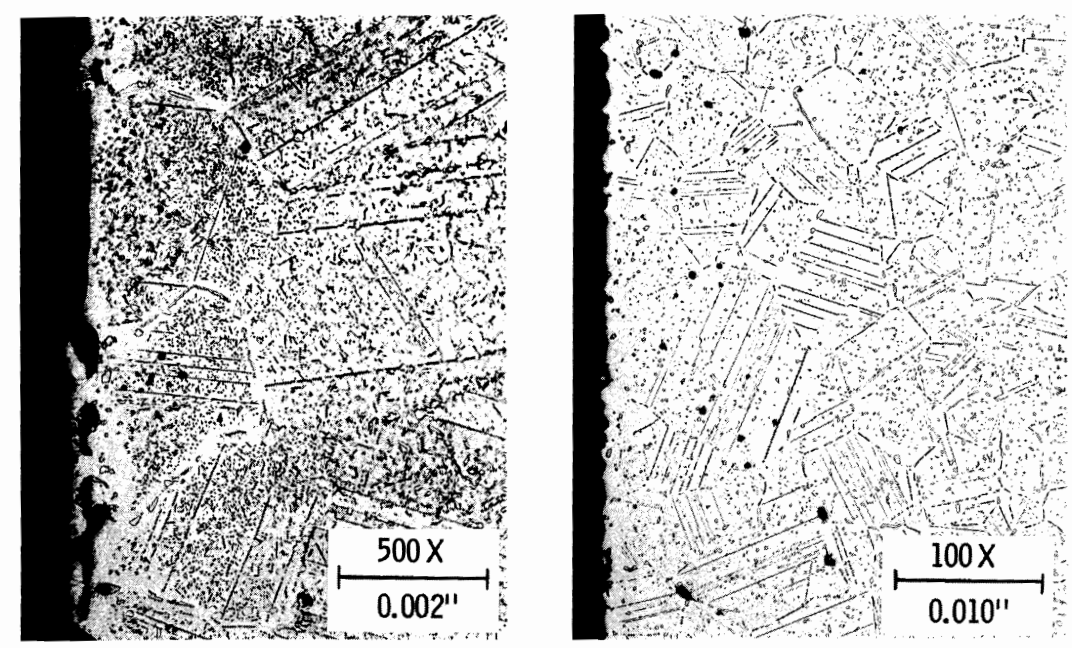

ETCHED

FIGURE 5. Haynes Alloy 25 Specimens Exposed to Nonradioactive $5 r F$ for $30,000 \mathrm{~h}$ - Capsule $S / \mathrm{V}=4.5 \mathrm{~cm}-1$ 
$600^{\circ} \mathrm{C}$

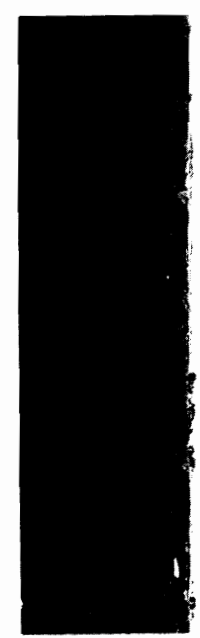

$\frac{500 X}{0.002^{\prime \prime}}$

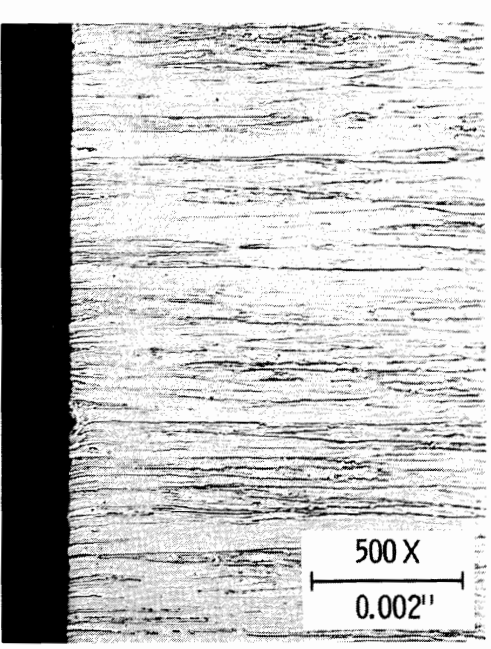

$800^{\circ} \mathrm{C}$

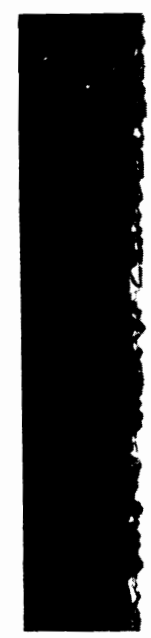

$1000^{\circ} \mathrm{C}$

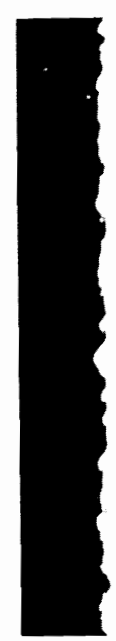

$\frac{500 X}{0.002^{11}}$

AS-POLISHED
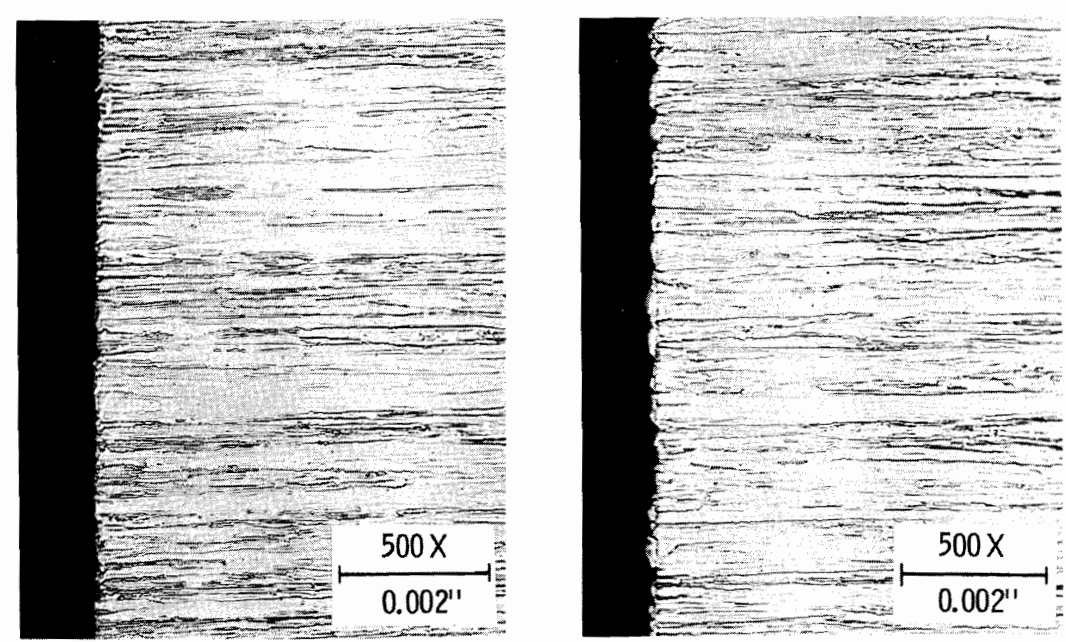

ETCHED .

FIGURE 6. TZM Specimens Exposed to Nonradioactive $S r F 2$ for $30,000 \mathrm{~h}$ - Capsule $S / \mathrm{V}=4.5 \mathrm{~cm}-1$ 
TASK 3 - CAPSULE QUALIFICATION AND LICENSING (D. G. Atteridge)

\section{Capsule Design}

The initial drafts of two topical reports on the design of the heat-source outer capsule were reviewed and approved by ANSP. The reports are Stress Analysis and Testing of the Outer Capsule Design for the Strontium Heat Source Development Program by F. A. Simonen, R. J. Shippe11, and D. G. Atteridge, and Collapse of Experimental Capsules Under External Pressure by F. A. Simonen and R. J. Shippell. The reports will be issued during the first quarter of FY 1980.

\section{Capsule Fabrication and Testing}

The prototype capsules to be used in the qualification testing program have been fabricated and welded. Five Hastelloy C-276 inner capsules were obtained from Rockwell Hanford, and are the standard inner capsules used in the WESF ${ }^{90} \mathrm{SrF}_{2}$ storage capsule. The inner capsules were filled with nonradioactive $\mathrm{SrF}_{2}$ and seal-welded. The inner capsules were inserted into the outer capsules that are to be subjected to the $30-\mathrm{ft}$ drop test.

A total of fifteen Hastelloy $S$ and seven Hastelloy $\mathrm{C}-4$ prototype outer capsules were fabricated and welded by the Stellite Division of the Cabot Corporation. The fabrication, inspection, and welding at Cabot was arranged and overseen by R. C. Lawrence of Pacific Northwest Laboratory (PNL). He delivered the inner capsules to Cabot, inspected the outer capsule components after fabrication, and was present during capsule welding. All capsules are now welded and have arrived at or are on their way to PNL.

The high-pressure autoclave and the high-temperature capsule-aging furnaces needed for the qualification testing of the prototype capsules were also checked out this quarter. The autoclave to be used for the 1000-bar hydrostatic pressure test was he1d at 15,000 psi for a week without problems. The high-temperature furnaces to be used for long-term aging of the prototype capsules were brought up to operating temperature and held there without incident.

A total of four Hastelloy S and two Hastelloy C-4 prototype capsules will be qualification-tested in the as-fabricated condition. The testing will begin as soon as the capsule welds have been radiographed. The remaining prototype capsules will be thermally aged in air for $8000 \mathrm{~h}$ and then subjected to the qualification tests. The aging temperatures have not been finalized, but will probably be $650^{\circ} \mathrm{C}$ and $725^{\circ} \mathrm{C}$.

Oxidation of Hastelloy S and Hastelloy C-4 (H. T. Fullam)

Electron microprobe analysis of the Hastelloy $S$ and Hastelloy $\mathrm{C}-4$ specimens heated in air at $600^{\circ}$ to $800^{\circ} \mathrm{C}$ for $10,000 \mathrm{~h}$ has been completed. Interpretation of the results is now under way.

The 2500- $h$ tests to determine the effect of air oxidation at $600^{\circ}$ to $800^{\circ} \mathrm{C}$ on the impact properties of Hastelloy $S$ and Hastelloy $C-4$ have been completed. Room-temperature testing of the oxidized specimens will be carried out in the first quarter of FY 1980. 
No. of

Copies

\section{OFFSITE}

\author{
A. A. Churm \\ DOE Patent Division \\ 9800 S. Cass Avenue \\ Argonne, IL 60439 \\ N. Goldenberg \\ DOE Advanced Nuclear Systems and \\ Projects Division \\ Washington, DC 20545
}

T. J. Dobry, Jr.

DOE Advanced Nuclear Systems and Projects Division

Washington, DC 20545

T. J. Holleman

DOE Advanced Nuclear Systems and Projects Division

Washington, DC 20545

A. P. Litman

[0. Advanced Nuclear Systems and Projects Division

Washington, DC 20545

J. J. Lombar do

DOE Advanced Nuclear Systems and Projects Division

Washington, DC 20545

3 W. C. Remini

DOE Advanced Nuclear Systems and Projects Division

Washington, DC 20545

B. J. Rock

DOE Advanced Nuclear Systems and Projects Division

Washington, DC 20545

N. R. Thielke

DOE Advanced Nuclear Systems and Projects Division

Washington, DC 20545

J. M. Maddox

$\mathrm{DOE}$

E201

Washington, DC 20545

C. A. Cooley

DOE Waste Management Division

Washington, DC 20545
No. of

Copies

D. C. Davis, Jr.

DOE Oak Ridge Operations Office

P.0. Box E

Oak Ridge, TN 37830

W. T. Goldston

DOE Savannah River Operations

Office

P.0. Box A

Aiken, SC 29801

27 DOE Technical Information Center

L. J. Jardine

Argonne National Laboratory

9700 South Cass Avenue

Argonne, IL 60439

W. R. Pardue

Battelle Columbus Laboratories

$505 \mathrm{King}$ Avenue

Columbus, $\mathrm{OH} 43201$

R. T. Huntoon

E. I. duPont deNemours and Company Savannah River Laboratory

Aiken, SC 29801

E. H. Cooke-Yarborough

Electronics and Applied Physics Division

Building 347.3, AERE Harwell

0Xfordshire OX11 ORA

GREAT BRITAIN

H. C. Carney

General Atomic Company

P.0. Box 81601

San Diego, CA 92138

S. E. Bronisz

Los Alamos Scientific Laboratory

P.0. Box 1663

Los Aiamos, NM 87544

R. A. Kent

Los Alamos Scientific Laboratory

P.0. Box 1663

Los ATamos, NM 87544

R. N. R. Mulford

Los Alamos Scientific Laboratory

P.0. Box 1663

Los Alamos, NM 87544 
No. of Copies

W. T. Cave

Monsanto Research Corporation

Mount Laboratory (DOE)

Nuclear Operations

P.0. Box 32

Miamisburg, OH 45342

R. Dewitt

Mons anto Research Corporation

Mount Laboratory (DOE)

Nuclear Operations

P.0. Box 32

Miamisburg, OH 45342

Department of the Army

Headquarters, U.S. Army

Facilities Engineering Support Agency

Ford Belvoir, VA 22060

H. H. Musselman, Tech. Dir.

Officer in Charge

Lt. J. H. Vogt

Naval Nuclear Power Unit

Code 70

Port Hueneme, CA 93043

2 A. A. Arcuni

Naval Facilities Engineering Command

Office of Special Assistant -

Nuclear Programs (04N)

200 Stovall Street

Alexandria, VA 22332

R. S. Crouse

Oak Ridge National Laboratory

Oak Ridge, TN 37830

K. W. Haff

Oak Ridge National Laboratory

Oak Ridge, TN 37830

J. Hammond

Oak Ridge National Laboratory

Oak Ridge, TN 37830

J. R. Keiser

Oak Ridge National Laboratory

Oak Ridge, TN 37830

E. Lamb

Oak Ridge National Laboratory

Oak Ridge, TN 37830

A. C. Schaffhauser

Oak Ridge National Laboratory

Oak Ridge, TN 37830

P. Dick

Teledyne Energy Systems

110 W. Timonium Road

Timonium, MD 21093
No. of

Copies

R. Hannah

Teledyne Energy Systems

110 W. Timonium Road

Timonium, MD 21093

W. A. McDonald

Teledyne Energy Systems

110 W. Timonium Road

Timonium, MD 21093

P. Vogelberger

Teledyne Energy Systems

110 W. Timonium Road

Timonium, MD 21093

C. C. Silverstein

Westinghouse Astronuclear Laboratory

P.0. Box 10864

Pittsburgh, PA 15236

ONSITE

4 DOE Rich 1 and Operations

W. A. Burns

D. Bogon

R. E. Gerton

H. E. Ransom

8 Rockwell Hanford Operations

L. I. Brecke

H. H. Hopkins

J. D. Kaser

E. J. Kosiancic

T. H. May

D. Ramey

J. P. Sloughter

C. R. Stroup

21

Pacif ic Northwest Laboratory

D. G. Atteridge

S. D. Dahlgren

H. T. Full am (3)

M. H. Henry

R. P. Marshall

R. E. Nightingale

N. J. Olson

L. D. Perrigo

A. M. Platt

W. E. Sande

F. A. Simonen

H. H. Van Tuyl

Technical Files (5)

Publishing Coordination YO(2) 